\title{
KOMUNIKASI SYNCHRONOUS DAN ASYNCHRONOUS DALAM E-LEARNING PADA MASA PANDEMIC COVID-19
}

\author{
Muhammad Hanif Fahmi \\ Program Studi Sistem Informasi, F. Saintek, Universitas Islam Raden Rahmat \\ J1. Raya Mojosari No. 02 Kepanjen, Malang \\ hanif@uniramalang.ac.id
}

\begin{abstract}
The impact of the Corona Virus Disease 2019 (Covid-19) pandemic requires educational institutions to implement Learning from Home (BDR) activities through the online distance learning method (PJJ daring) using e-learning. Educational institutions that have been using direct communication in learning have switched to learning using online media (mediated communication). Some communication media in e-learning can only run in synchronous or asynchronous mode, some others can run in both modes. This study aims to determine the preferences of educators and students in choosing the type and communication media used in e-learning in the implementation of BDR. Qualitative methods with a comparative descriptive approach are used to describe and compare the functions, advantages and disadvantages of each communication media as well as to see the preferences for the use of communication media in online distance learning. The learning process that occurs today, mostly uses a hybrid communication mode that combines synchronous and asynchronous communication. In choosing communication media that are used for PJJ daring (e-learning), educators consider several factors, including: data quota consumption, user friendly, network infrastructure conditions, and conformity to learning activities. So that educators and students have high preferences for several applications such as Whatsapp, Zoom Meeting, Google Meet, Microsoft team, Google Clasroom, Google forms, Quizziz to be used together.
\end{abstract}

Keyword: Synchronous Communication, Asynchronous Communication, Learning From Home, Online PJJ, E-learning

\begin{abstract}
Abstrak
Dampak dari pandemi Corona Virus Disease 2019 (Covid-19) mengharuskan satuan pendidikan menerapkan kegiatan Belajar Dari Rumah (BDR) melalui metode pembelajaran jarak jauh dalam jaringan (PJJ daring) menggunakan e-learning. Komunikasi dalam pembelajaran yang selama ini dilakukan secara langsung (direct communication) beralih ke pembelajaran menggunakan media daring (mediated communication). Sebagian media komunikasi dalam e-learning hanya dapat berjalan pada mode synchronous atau asynchronous, sebagian yang lain dapat berjalan pada kedua mode. Penelitian ini bertujuan untuk mengetahui preferensi pendidik dan peserta didik dalam memilih tipe dan media komunikasi yang digunakan dalam e-learning pada pelaksanaan BDR. Metode kualitatif dengan pendekatan deskriptif komparatif digunakan untuk menggambarkan dan membandingkan fungsi, kelebihan dan kekurangan masing-masing media komunikasi serta melihat preferensi penggunaan media komunikasi dalam PJJ daring. Proses pembelajaran yang berlangsung saat ini, sebagian besar menggunakan mode komunikasi hybrid yang mengkombinasikan komunikasi synchronous dan asynchronous. Dalam memilih media komunikasi yang dimanfaatkan untuk PJJ daring (e-learning), pendidik mempertimbangkan beberapa faktor, antara lain: konsumsi kuota data, kemudahan penggunaan (user friendly), kondisi infrastruktur jaringan, serta kesesuaian dengan aktivitas pembelajaran. Sehingga
\end{abstract}


pendidik dan peserta didik memiliki preferensi yang tinggi terhadap beberapa aplikasi seperti Whatsapp, Zoom Meeting, Google meet, Microsoft team, Google Clasroom, Google form, Quizziz untuk digunakan secara bersama-sama.

Kata Kunci: komunikasi synchronous, komunikasi asynchronous, Belajar Dari Rumah, PJJ daring, E-learning

\section{PENDAHULUAN}

Pandemi corona virus disease 2019 (Covid-19) membawa dampak pada seluruh aspek kehidupan manusia, termasuk dalam bidang pendidikan. Sebelum terjadi pandemi covid-19 model pembelajaran yang diterapkan pada hampir seluruh lembaga pendidikan di Indonesia adalah model pembelajaran tatap muka. Peserta pendidik dan pendidik hadir di tempat yang sama, biasanya ruang kelas, untuk melaksanakan kegiatan belajar mengajar secara langsung.

Pada saat terjadi pandemi covid-19 seluruh kegiatan sosial masyarakat harus mematuhi protokol kesehatan yang telah ditetapkan oleh Kementrian Kesehatan. Protokol kesehatan tersebut tertuang dalam Pedoman Pencegahan dan Pengendalian Corona Virus Disease 2019 (Covid-19). Sejak WHO mengumumkan kondisi darurat atas wabah covid-19, Indonesia juga mengukuti beberapa kebijakan dalam segala aspek kehidupan. Mulai dai pendidikan, kesehatan, kehidupan sosial,politik bahkan budaya baru dibentuk untuk mengantisipasi penyebarannya. Upaya yang dilakukan di daerah adalah menciptakan stategi komunikasi kepada masyarakat wilayahnya masing-masing melalui teknik koersif, informatif, canalizing, edukatif, persuasif dan berulang dalam mengemas pesan berupa instruksi, himbauan kepada masyarakat untuk mencegah penularan Covid-19 di wilayahnya masing-masing. Langkah konkritnya adalah membuat strandart protokol kesehatan yang diberlakukan secara nasioanl (Zahrotunnimah, 2020)
Isbaniah (2020) menjelaskan protokol kesehatan yang diterapkan secara nasional meliputi jaga jarak, memakai masker, cuci tangan dengan sabun, menghindari kerumunan, isolasi mandiri dan meminimalisir kegiatan di luar rumah. Dalam Yunus \& Rezki (2020), protokol keshatan tersebut sangat berdampak terhadap perubahan kebiasaan masyarakat dan pola komunikasi. Termasuk kebijakan lockdown mengubah kebiasaan terutama dalam bidang pendidikan.

Kebijakan lockdown pada awalnya sangat memberatkan penduduk dan sangat berdampak di berbagai negara. Di Indonesia lockdown diberi Pembatasan berskala besar. Pada masa awal penyebaran covid-19 di Indonesia yaitu pada bulan maret 2020, kebijakan Sebagai pengganti pertemuan tatap muka, maka sekolah diintruksikan untuk melaksanakan kegiatan pembelajaran jarak jauh melalui media daring (Prodjo, 2020).

Kajian tentang pembelajaran online dan kepuasan hasil pembelajaran menjelaskan terdapat ketidakpuasan terhadap hasil. Hal ini dipengaruhi oleh berbagai faktor antara lain: kualitas mutu pembelajaran, waktu serta penerimaan peserta didik (Aji, 2020; Napitupulu, 2020; Satrianingrum, A. P., \& Prasetyo, 2020). Faktor utama yang menentukan keberhasilan daring adalah kesiapan tenaga pendidik, peserta didik atas penguasaan media teknologi dalam mengkombinasikan dengan materi yang diajarkan. Seperti misalnya dalam Ayuni., et al (2020), pembelajaran daring dengan tutorial memiliki pengaruh yang signifikan terhadap pemahaman peserta didik. Hal yang sama juga terjadi pada 
pembelajaran di tingkat dasar. Bahwa metode video tutorial mampu membangkitkan persepsi peserta pendidik dalam menerima penjelasan dari pendidik (Dewi, 2020).

Dari penjelasan di atas kekuatan dari pembelajaran jarak jauh terletak pada penguasaan materi dan penggunaan media komunikasi. Dalam proses pembelajaran, media komunikasi yang sering digunakan adalah media elektronik sehingga dikenal juga dengan istilah electronic learning ( $e$ learning). Pada masa normal metode pembelajaran e-learning digunakan untuk mengatasi kendala-kendala yang ada pada perkuliahan tatap muka diantaranya keterbatasan ruang kelas dan jumlah kehadiran dosen dan peserta pendidik dikelas. Selain itu e-learning dipilih karena fleksibilitasnya yang tinggi, pembelajaran bisa dilakukan dari manapun melalui media website dan mobile (Fahmi \& Cipta, 2020).

Ketika kebijakan pembelajaran jarak jauh diterapkan, hampir seluruh pihak yang terlibat dalam pembelajaran jarak jauh yaitu pendidik, peserta pendidik dan orang tua mengalami kegagapan dalam pemanfaatan media e-learning. Karena memang sebagian besar sekolah di Indonesia selama ini fokus pada pembelajaran tatap muka. Belum banyak lembaga pendidikan yang mengembangkan pembelajaran jarak jauh (PJJ) sehingga sekolah belum memiliki Learning Management Systems yang dikembangkan dan diterapkan dalam pembelajaran di sekolah. Penggunaan media komunikasi elektronik penunjang PJJ seperti google classroom, schoology dan edmodo masih belum terlalu dikenal oleh civitas pendidikan.

Selain itu, kendala yang beragam juga menjadi penghambat transformasi pendidikan berbasis PJJ di Indonesia. Kendala tersebut meliputi geografis (Taradisa., et al, 2020), kemampuan pemanfaatan media (Almah., et al, 2020), sistem informasi, pengawasan, dan akses internet (Rigianti, 2020). Inovasi formula untuk mengatasi permasalahan pembelajaran daring masih terus dikembangkan untuk diadaptasikan terhadap kondisi geografis, sumber daya manusia serta budaya yang ada di Indonesia. Geografis menjadi kendala terbesar dikarena Indonesia merupakan negara kepulauan. Selain itu sarana dan prasarana yang berkaitan dengan teknologi komunikasi belum terdistribusikan dengan merata.

Tantangan di dunia pendidikan saat pandemi adalah metode pembelajaran yang selama ini terbiasa tatap muka langsung (direct communication) beralih ke pembelajaran menggunakan media online (mediated communication). Peserta pendidik belajar dari rumah menggunakan metode $e$ learning melalui media komunikasi daring yang ditentukan dan disiapkan oleh masingmasing pendidik. Masalahnya adalah ada pada ketidaksiapan antara penyelenggara pendidikan dan peserta didik.

Fenomena semacam ini dapat dikatakan sebagai gegar budaya dan gegar teknologi. Kekagetan masyarakat terutama dalam pemanfaatan media belajar online dan menjalankan peran baru juga menjadi penyebab kedua hal tersebut terjadi. Dalam Maizan, et al, (2020) perubahan kebiasaan konvensional berubah menjadi aktivitas berbasis teknologi membawa ke dalam gegar budaya dan teknologi. Sama halnya dengan penyelenggaraan pendidikan di era pandemi mengalami kekagetan karena secara spontan bermigrasi pada pembelajaran daring.

Hambatannya adalah upaya yang dilakukan oleh pendidik dan peserta didik harus berkesinambungan guna hasil maksimal. Fenomena proses belajar dari rumah, sebagian besar sekolah belum siap untuk menerapkannya. Dari sisi peserta didik tidak memiliki fasilitas yang memadai untuk melakukan e-learning. Berdasarkan hasil survei Astini (2020), 50\% peserta didik tidak memiliki laptop, dan $80 \%$ sulit mendapatkan sinyal dan boros dalam menggunakan 
rencana data karena tempat tinggalnya tinggal jauh dari daerah perkotaan.

Masa pandemi ini memberikan efek luar biasa terhadap pertumbuhan teknologi khususnya dalam dunia pendidikan. Namun, juga menuntut untuk menyediakan sistem yang terintegrasi dan mampu memenuhi kebutuhan pembelajaran online. Dari sisi infrastruktur rata-rata sekolah di Indonesia belum memiliki Learning Menagement System (LMS) yang di Dalam pelaksanaannya banyak media komunikasi $e$ learning yang digunakan, mode singkron asinkron (Asmuni, 2020). Tidak hanya itu, kesiapan pendidik juga menjadi permaslahan tersendiri harus dengan cepat menyesuaikan metode penyampaian materi dan konten dari materi.

Menjawab tantangan komunikasi dalam elearning di masa pandemi institusi pendidikan memasuki era new normal institusi pendidikan membiasakan diri untuk menggunakan media terkonologi. Pemanfaatan ini bukan lagi sebagai media pilihan, melainkan menjadi media penopang yang dominan digunakan dalam setiap kali penyelenggaraan proses belajar mengajar. Model komunikasi beralih pada komunikasi berbasis media teknologi. Berdasarkan model komunikasi, PJJ daring dapat dibagi menjadi 2 kategori: synchronous dan asynchronous.

\footnotetext{
Dalam Suranto (2019), PJJ daring synchronous, yaitu interaksi yang berorientasi pada pembelajaran dan difasilitasi dengan intruksi secara langsung, real-time dan biasanya terjadwal. Sedangkan menurut Darmawan (2018), PJJ daring asynchronous dapat diartikan sebagai pembelajaran secara independen dimana peserta didik dapat berinteraksi satu sama lain dengan materi yang telah disediakan pada waktu yang mereka pilih. Kedua model pembelajaran ini sering kali dikombinasikan untuk saling menutupi kekurangannya. Tujuan dari penelitian ini adalah untuk mengetahui preferensi pendidik dan peserta didik dalam memilih tipe dan media
}

komunikasi yang digunakan dalam pelaksanaan PJJ daring dalam rangka Belajar Dari Rumah (BDR) di masa pandemic Covid19.

\section{METODE PENELITIAN}

Penelitian ini menggunakan metode deskriptif komparatif. Metode ini dipilih agar dapat menggambarkan dan membandingkan fungsi, kelebihan dan kekurangan masingmasing media komunikasi. Dimana media tersebut digunakan dalam e-learning pada saat pandemic. Serta melihat kombinasi media yang sesuai dengan kondisi di Indonesia. Penelitian ini merupakan penelitian dari studi literatur kualitatif yang melakukan eksplorasi dan analisis data kualitatif. Sumber data didapat dari observasi dan studi literatur dari berbagai sumber.

Peneliti membagi tahapan penelitian menjadi 2 tahap. Tahap pertama adalah analisis media komunikasi sinkronus dan asinkronus yang dimanfaatkan untuk elearning. Tahap kajian literatur untuk membandingkan keduanya. Kedua tahap tersebut lalu dikomparasikan dan dianalisis secara kritis terkait pemanfaatan dan urgensinya yang disesuaikan dengan kondisi pandemi.

Sedangkan kegiatan analisis data meliputi: persiapan, mentabulasi data, dan penerapan data. Kegiatan pada saat persiapan ini adalah: mengecek kelengkapan identitas pengisi, mengecek kelengkapan data, mengecek macam isian data. Sedangkan pada pentabulasian dilakukan dengan cara: tabulasi data, penyimpulan data, analisis data untuk tujuan penarikan kesimpulan.

\section{HASIL DAN PEMBAHASAN}

\section{Kebijakan Model Pembelajaran di Masa Pandemi Covid-19}

Kasus covid-19 pertama di Indonesia terkonfirmasi pada 2 Maret 2020.(Kompas, 2020). Pada awal masa pandemi, sebenarnya 
belum ada wacana dari Kemendikbud untuk meliburkan sekolah, meskipun jumlah kasus terus naik. Surat edaran Mendikbud no. 3 tahun 2020 yang diterbitkan tanggal 9 maret 2020 hanya menekankan pada satuan pendidikan untuk menyediakan fasilitas cuci tangan pakai sabun (CTPS) dan penerapan perilaku hidup bersih sehat (PHBS) dilingkungan satuan pendidikan.

Meskipun begitu, beberapa kepala daerah mengambil inisiatif untuk meliburkan sekolah selama 2 minggu, antara lain Provinsi DKI Jakarta, Provinsi Jawa Tengah, Banten, Kota Bogor, kota Bekasi (Tempo, 2020). Setelah itu, baru pada tanggal 24 maret 2020, Mendikbud mengeluarkan Surat Edaran No. 4 tahun 2020 tentang Pelaksanaan Kebijakan Pendidikan dalam Masa Darurat Penyebaran Coronavirus Disease (Covid-19) yang diantaranya mengatur tentang proses belajar dari rumah.

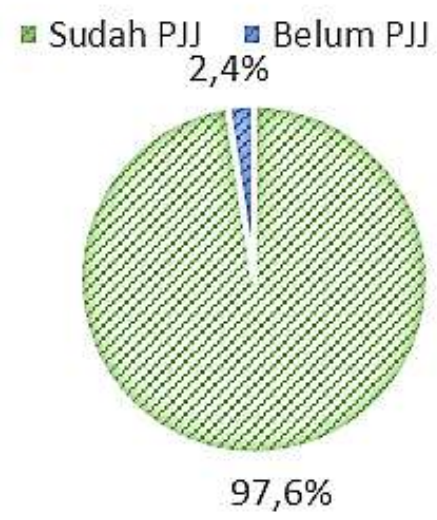

Gambar 2. Grafik Pelaksaan PJJ di Indoensia (CNNI, 2020)

Kebijakan tersebut diambil untuk melindungi warga satuan pendidikan dari potensi terpapar covid. Sekolah memiliki resiko tinggi dalam penyebaran covid-19 karena setiap harinya terdapat aktivitas berkumpul pendidik dan peserta pendidik serta orang tua yang mengantar atau menjemput (Arifa, 2020). Dan dari gambar 1 dapat dipastikan bahwa 97,6\% PJJ telah dilakukan meskipun kualitas pemeblajarannya kurang berkualitas. Rata- rata hanya untuk pemenuhan dan hanya sekedar menuntaskan proses pembelajaran selama satu semester. Dengan kata lain banyak tindakan permisif dalam proses pembelajaran karena kondisi dikategorikan dalam keadaan tidak biasa dan kondisi luar biasa.

Ketika surat edaran tersebut dikeluarkan, Dirjen PAUD, Pendidikan Dasar, dan Menengah Kemendikbud mencatat sebanyak 97,6 \% sekolah sudah memberlakukan pembelajaran jarak jauh. Sedangkan yang $2,4 \%$ belum melakukan karena daerahnya belum terjangkit atau karena perangkat pendukung tidak memadai. Lembaga pendidikan mengalami kegaduhan dikarenakan format pendidikan yang selama ini terbiasa dengan tatap muka tidak bisa dilakukan secara massif. Selain itu, juga sempat mengalami kebuntuan dalam hal pembelajaran dari rumah.

Ketidaksiapan nampak terlihat pada tiga elemen lembaga pendidikan, peserta didik dan orang tua. Pihak lembaga pendidikan dibagi lagi menjadi lebih spesifik yakni kepala sekolah dan jajarannya atau jajaran pimpinan di pendidikan tinggi terkait sistem penyelenggaraan pembelajaran. Sedangkan pendidik juga mengalami kesulitan dalam metode penyampaian kepada peserta didik. Pengemasan materi juga berubah total mengingat banyak waktu yang terbuang karena penyesuaian dengan media belajar.

Pelaksanaan pembelajaran daring selama pandemi Covid-19 memiliki berbagai permasalahan yang dialami oleh pendidik, peserta pendidik, dan orang tua. Permasalahan pendidik berupa lemahnya penguasaan IT dan keterbatasan akses pengawasan peserta pendidik, dari peserta pendidik berupa tidak aktif dalam pembelajaran, keterbatasan fasilitas pendukung dan akses jaringan internet, sedangkan dari orang tua dalam bentuk keterbatasan waktu dalam mendampingi anaknya selama belajar online. Berbagai 
permasalahan ini dapat diatasi dengan meningkatkan kompetensi dalam penguasaan IT, pengawasan intensif dengan melibatkan peran orang tua, dan memberikan penugasan manual.

\section{Masa Kenormalan Baru dan Tahun Ajaran Baru 2020/2021}

Memasuki masa kenormalan baru, 4 kementerian menerbitkan Keputusan bersama yaitu Kementerian Pendidikan dan Kebudayaan, Kementerian Agama, Kementerian Kesehatan, Kementerian Dalam Negeri tentang panduan penyelenggaraan pembelajaran pada tahun ajaran 2020/2021. Keputusan ini berisi meskipun mengijinkan sekolah untuk melaksanakan pembelajaran tatap muka tetapi pada prinsipnya tetap memprioritaskan kesehatan dan keselamatan peserta didik, pendidik, tenaga kependidikan dan masyarakat.

Berdasarkan prinsip tersebut maka, Pembelajaran tatap muka hanya diperbolehkan untuk daerah yang sudah masuk zona hijau dalam kategorisasi yang dilakukan oleh Satgas Covid-19. Sedangkan pembelajaran di daerah zona merah, oranye dan kuning, tetap menggunakan model Belajar Dari Rumah (BDR) melalui media komunikasi dalam jaringan (daring). Kebijakan tersebut dapat dilihat pada tabel dibawah ini:

Tabel 1 Model Pembelajaran

\begin{tabular}{|c|c|l|}
\hline $\begin{array}{c}\text { Level } \\
\text { Risiko }\end{array}$ & $\begin{array}{c}\text { Awal TA. } \\
\text { 2020/2021 }\end{array}$ & $\begin{array}{c}|c| \\
\text { Model } \\
\text { Pembelajaran }\end{array}$ \\
\hline $\begin{array}{c}\text { Zona } \\
\text { Merah }\end{array}$ & Juli 2020 & $\begin{array}{l}\text { Belajar Dari } \\
\text { Rumah (BDR) }\end{array}$ \\
\hline $\begin{array}{c}\text { Zona } \\
\text { Oranye }\end{array}$ & Juli 2020 & $\begin{array}{l}\text { Belajar Dari } \\
\text { Rumah (BDR) }\end{array}$ \\
\hline $\begin{array}{c}\text { Zona } \\
\text { Kuning }\end{array}$ & Juli 2020 & $\begin{array}{l}\text { Belajar Dari } \\
\text { Rumah (BDR) }\end{array}$ \\
\hline
\end{tabular}

\begin{tabular}{|l|l|l|}
\hline $\begin{array}{l}\text { Zona } \\
\text { Hijau }\end{array}$ & Juli 2020 & Tatap Muka \\
\hline
\end{tabular}

Sumber: Keputusan Bersama 4 Kementerian

Pelaksanaan pembelajaran tatap muka pada zona hijau harus melalui proses pengambilan keputusan yang melibatkan seluruh pihak yang terkait dan memenuhi seluruh kriteria berikut:

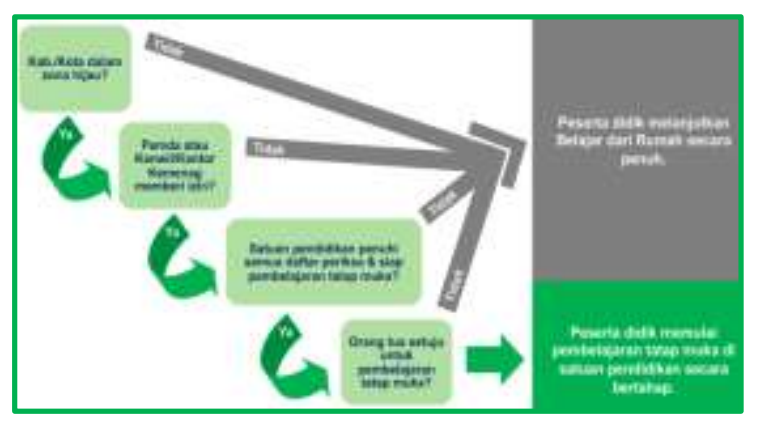

Gambar 3. Mekanisme Pelaksaan PJJ

Dari grafik tersebut bisa disimpulkan, pembelajaran tatap muka di zona hijau dapat dilakukan apabila telah mendapat ijin dari Pemda atau Kanwil/Kantor Kemenag, satuan pendidikan telah siap dan telah memenuhi daftar periksa kesiapan, serta orang tua setuju dengan pelaksanaan pembelajaran tatap muka. Selain harus memenuhi kriteria tersebut diatas, penerapan pembelajaran tatap muka dilakukan secara bertahap. Urutan tahapan ditentukan berdasarkan tingkat kemampuan peserta didik dalam menerapkan protokol kesehatan, yaitu dimulai dari tahap pertama untuk tingkat SMA dan SMP, tahap kedua untuk tingkat SD/MI serta tahap ketiga untuk tingkat PAUD.

Berdasarkan SKB empat mentri, apabila dalam tahapan pelaksanaan pembelajaran tatap muka terdapat penambahan kasus covid-19 atau level risiko daerah naik, satuan pendidikan wajib ditutup kembali. Dengan kata lain, new normal masih belum membawa kondisi pendidikan menjadi lebih baik. Dalam hal ini masih banyak lembaga pendidikan yang masih dalam proses penyesuaian diri atas pemanfaatan pembelajaran jarak jauh. Bahkan lebih 
kritisnya, lembaga pendidikan juga kurang berhasil dalam proses belajar mengajar secara daring.

\section{Komparasi Media Pembelajaran Synchronous dan Asynchronous}

Secara teknis pelaksanaan belajar dari rumah yang dilaksanakan oleh seluruh satuan pendidikan di Indonesia saat ini mengacu pada pedoman penyelenggaraan BDR yang tertuang dalam Surat Edaran (SE) Sekretaris Jendral Kementerian Pendidikan dan Kebudayaan No. 15 tahun 2020. Dalam SE tersebut antara lain memberikan penjelasan terkait metode dan media yang digunakan dalam BDR. Pendekatan dalam Metode Pembelajaran Jarak Jauh (PJJ) yang digunakan dalam BDR dibagi menjadi 2, yaitu: Pembelajaran jarak jauh dalam jaringan (daring) dan Pembelajaran jarak jauh luar jaringan (luring). Satuan pendidikan dapat memilih salah satu atau kombinasi dari kedua pendekatan (Kementerian Pendidikan Dan Kebudayaan, 2020).

Proses Pembelajaran jarak jauh dalam jaringan (daring) merupakan metode PJJ yang terdiri dari kegiatan (1) tatap muka virtual dalam bentuk video conference, video call, teleconference, dan atau diskusi dalam grup di media sosial atau aplikasi pesan instan; (2) menggunakan Learning Management System (LMS). Aktivitas pembelajaran yang dilakukan melalui LMS antara lain: pemberian materi belajar, pemberian dan pengumpulan tugas, konsultasi, umpan balik tugas, evaluasi pembelajaran (Kementerian Pendidikan Dan Kebudayaan, 2020).

Pembagian pendekatan oleh kemendikbud tersebut secara prinsip sebenarnya sama dengan kategorisasi $e$ learning berdasarkan tipe komunikasinya yaitu komunikasi synchronous dan komunikasi Asynchronous. PJJ daring dengan pendekatan tatap muka virtual merupakan penerapan komunikasi synchronous, dimana komunikasi dalam proses pembelajaran antara pendidik dan peserta didik dilakukan secara realtime atau pada saat yang sama. Sedangkan LMS menggunakan komunikasi Asynchronous dimana pendidik dan peserta didik tidak bertemu pada ruang virtual secara bersamaan.

Meskipun kemendikbud memberi rekomendasi media dan sumber belajar yang dapat digunakan, tetapi sekolah dan pendidik tetap diberi keleluasaan dalam memilih media dan sumber belajar yang digunakan. Pemilihan media dan sumber belajar disarankan untuk mempertimbangkan kondisi suatu wilayah, ketersediaan sarana dan prasarana serta kesiapan dan kesepakatan pendidik dengan peserta didik atau orang tua/wali. Dampak dari kebijakan tersebut, platform atau media komunikasi yang digunakan dilapangan menjadi sangat bervariasi. Dari sekian banyak media aplikasi yang ada tidak semua aplikasi digunakan oleh pendidik dan peserta pendidik dalam proses PJJ daring. Pada awalnya pendidik memilih dan mencoba beberapa aplikasi yang menurut pendidik user friendly baik bagi pendidik, peserta pendidik maupun orang tua/wali peserta pendidik yang mendampingi proses pembelajaran. Seiring berjalannya waktu serta berdasarkan pengalaman satuan pendidikan, para pendidik, peserta pendidik dan orang tua dalam memanfaatkan berbagai media komunikasi yang tersedia, pada akhirnya hanya beberapa media komunikasi saja yang menjadi pilihan utama dan selalu digunakan pendidik dalam kegiatan PJJ daring.

Pilihan tersebut disebabkan karena beberapa alasan, antara lain kemudahan penggunaan, kesesuain dengan aktivitas pembelajaran, serta biaya yang harus dikeluarkan (Daheri, Juliana, Deriwanto, \& Amda, 2020). Pada prakteknya pendidik atau satuan pendidikan menggunakan lebih dari satu aplikasi sebagai media komunikasi dalam PJJ daring. Media komunikasi yang 
banyak digunakan dalam PJJ daring antara lain tersaji dalam tabel 2.

Tabel 2 Media Komunikasi PJJ Daring

\begin{tabular}{|l|l|l|}
\hline Nama & $\begin{array}{l}\text { Tipe } \\
\text { Komunikasi }\end{array}$ & Kategori \\
\hline $\begin{array}{l}\text { Whatsapp } \\
\text { (WA) }\end{array}$ & $\begin{array}{l}\text { Synchronous } \\
\text { dan } \\
\text { asynchronous }\end{array}$ & $\begin{array}{l}\text { Instan } \\
\text { Messaging, } \\
\text { VoIP }\end{array}$ \\
\hline $\begin{array}{l}\text { Zoom } \\
\text { Meeting }\end{array}$ & Synchronous & $\begin{array}{l}\text { Video } \\
\text { Conferencing }\end{array}$ \\
\hline $\begin{array}{l}\text { Google } \\
\text { Meet }\end{array}$ & Synchronous & $\begin{array}{l}\text { Video } \\
\text { Conferencing }\end{array}$ \\
\hline $\begin{array}{l}\text { Microsoft } \\
\text { Team }\end{array}$ & Synchronous & $\begin{array}{l}\text { Video } \\
\text { Conferencing }\end{array}$ \\
\hline $\begin{array}{l}\text { Google } \\
\text { Clasroom }\end{array}$ & Asynchronous & LMS \\
\hline Edmodo & Asynchronous & LMS \\
\hline Moodle & Asynchronous & LMS \\
\hline Youtube & $\begin{array}{l}\text { Synchronous } \\
\text { dan } \\
\text { Asynchronous }\end{array}$ & $\begin{array}{l}\text { Streaming } \\
\text { Video, Video } \\
\text { on Demand }\end{array}$ \\
\hline $\begin{array}{l}\text { Google } \\
\text { Form }\end{array}$ & Asynchronous & $\begin{array}{l}\text { Formulir } \\
\text { cloud }\end{array}$ \\
\hline $\begin{array}{l}\text { Google } \\
\text { Drive }\end{array}$ & Asynchronous & $\begin{array}{l}\text { Penyimpanan } \\
\text { cloud }\end{array}$ \\
\hline $\begin{array}{l}\text { Quizziz } \\
\text { Gamifikasi } \\
\text { Tugas }\end{array}$ \\
\hline Gmail & Asynchronous & \begin{tabular}{l} 
Email \\
\hline
\end{tabular} \\
\hline
\end{tabular}

Tabel 2 menunjukkan bahwa satu aplikasi dapat digunakan hanya untuk salah satu mode komunikasi yaitu synchronous atau asynchronous saja. Tetapi terdapat juga aplikasi-aplikasi yang dapat berjalan untuk tipe komunikasi synchronous dan asynchronous, bergantung pada kebutuhan.

Sebelum masa pandemi covid-19, jika kita membicarakan e-learning, pembelajaran jarak jauh, atau pembelajaran daring, maka berasosiasi sangat erat dengan penggunaan Learning Management System (LMS) seperti moodle, google classroom atau Edmodo. LMS lebih difungsikan sebagai media komunikasi asynchrounus yang digunakan untuk mengelola pembelajaran secara daring, antara lain manajemen materi, proses dan evaluasi pembelajaran serta mengelola tugas dan ujian (Fahmi \& Cipta, 2020). Untuk dapat menggunakan moodle, maka sekolah harus menginstall aplikasi ini pada server atau hosting yang dimiliki oleh sekolah. Moodle memiliki fitur yang sangat lengkap yang dibutuh dalam pelaksanaan PJJ daring, tetapi dibutuhkan keahlian yang baik untuk maintenance dan penggunaannya serta infrastruktur yang memadai. Sehingga sekolah dan pendidik yang belum pernah mengimplementasikan moodle, akan sulit mengadopsinya dalam waktu singkat untuk digunakan dalam pembelajaran dari di masa pandemi covid-19.

Berbeda dengan moodle, google classroom dan edmodo adalah aplikasi berbasis cloud yang dapat digunakan secara langsung oleh pendidik tanpa perlu proses installasi. Pendidik dan peserta pendidik cukup mendaftarkan diri atau membuat akun (sign up) melalui website. Kedua aplikasi ini juga lebih user friendly sehingga lebih mudah digunakan. Kekurangannya, pihak sekolah tidak dapat memantau proses pembelajaran yang terjadi seperti yang dapat dilakukan pada moodle. Selain itu LMS tidak dapat secara interaktif dalam berkomunikasi.

Sehingga pada awal pembelajaran, mayoritas pendidik akan membuat Whatsapp Group (WAG) yang beranggotakan peserta pendidik, jika peserta pendidik sudah memungkinkan untuk menggunakan HP sendiri. Untuk sekolah dasar, maka anggota WAG biasanya adalah orang tua peserta pendidik. Setelah itu komunikasi dan aktivitas pembelajaran dilakukan di dalam WAG tersebut.

Komunikasi yang dilakukan melalui WAG lebih banyak dalam bentuk asynchronous antara lain berinteraksi, diskusi grup dan menyampaikan pengumuman dan informasi melalui pesan teks. WA juga digunakan untuk memberikan materi melalui pesan suara dan menu berbagi file (gambar, video atau dokumen). Pendidik juga dapat 
memberikan penugasan melalui pesan teks berisi tugas yang harus dikerjakan disertai intruksi pengerjaan. Kebanyakan pendidik memberikan materi dan tugas sesuai dengan kurikulum dan jadwal pelajaran yang sudah ditentukan diawal tahun ajaran.

Alternatif lain, pendidik biasanya menambahkan external link yang mengarahkan peserta pendidik pada materi yang tersimpan di google drive atau youtube. Pendidik sebelumnya telah membuat materi berupa file yang diupload ke google drive. Beberapa pendidik membuat materi berupa video yang dapat dilihat di youtube.

\section{Sedangkan dalam melakukan assessment atau evaluasi pembelajaran biasanya pendidik membuat penugasan atau membuat soal yang dikirim melalui WA, kemudian peserta pendidik mengerjakan di buku tulis masing-masing. Hasilnya di foto dan dikirim melalui WA atau melalui google form, google classroom, moodle, Edmodo, atau email.}

Metode lain yang banyak diterapkan dalam penugasan atau evaluasi belajar, pendidik membuat kuis menggunakan fitur kuis yang ada pada LMS seperti moodle, google classroom atau Edmodo. Beberapa pendidik juga membuat kuis yang lebih interaktif dan menarik dengan aplikasi quizziz. Aplikasi ini menerapkan konsep gamifikasi kuis sehingga dalam mengerjakan soal peserta pendidik seperti sedang bermain game.

Metode pembelajaran seperti ini sangat menuntut kemandirian peserta pendidik dalam belajar. Peserta pendidik harus aktif membaca, melihat video dan mengerjakan tugas. Selain itu peran orang tua/wali juga menjadi sangat sentral, terutama pada level pendidikan tingkat dasar. Orang tua harus mampu manggantikan peran pendidik untuk menjelaskan seluruh materi pelajaran mulai dari Bahasa Indonesia, matematika, Bahasa inggris, PJOK, Bahasa daerah, kesenian, TIK, dan masih banyak lagi. Dimana pelajaran tersebut biasanya diajarkan oleh beberapa pendidik. Orang tua juga harus berkomunikasi melalui grup WA dengan pendidik.

Maka tidak heran jika penelitian yang dilakukan Mirzon Daheri, dkk. menyimpulkan bahwa mayoritas $(41,2 \%)$ orang tua meyakini bahwa pembelajaran menggunakan Whatsapp tidak efektif, sedangkan $33,3 \%$ orang tua meragukan efektifitasnya (Daheri et al., 2020).

Meskipun demikian, WA tetap menjadi pilihan utama pendidik dan peserta didik dalam melakukan komunikasi dan interaksi. Karena WA mudah digunakan sehingga pendidik tidak perlu menjelaskan lagi cara penggunaan WA kepada peserta pendidik dan orang tua/wali. Hal ini tidak terlepas dari popularitas WA yang sangat tinggi, dimana WA merupakan salah satu media sosial dengan pengguna global sebanyak 2 miliar orang. Sedangkan pengguna aktif di Indonesia sebanyak $84 \%$ dari 175,4 juta pengguna internet di Indonesia (Kemp, 2020). Bahkan bermedia melalui WAG sudah menjadi gaya hidup dan ritual baru yang tidak dapat ditinggalkan untuk meningkatkan eksistensi dan mengisi waktu luang (Setiyaningsih \& Jatmikowati, 2019). Selain itu dari sisi biaya, WA juga relatif lebih murah karena tidak membutuhkan kuota yang besar.

Sebenarnya sekolah dalam hal ini pendidik dapat memanfaatkan pendekatan pembelajaran daring yang lebih humanis dengan menggunakan media komunikasi synchronous seperti zoom meeting, google meet, Microsoft team, atau juga menggunakan WA melalui live chat atau video call/video conference. Aplikasiaplikasi tersebut awalnya didesain untuk melakukan rapat online, tetapi pada masa pandemi covid-19, banyak pendidik dan lembaga pendidikan memanfaatkannya untuk melakukan pembelajaran dan webinar. 
Melalui video conference pendidik dan peserta pendidik dapat melakukan tatap muka virtual. Pendidik dan peserta pendidik dapat berkomunikasi secara langsung meskipun berbeda lokasi. Dengan begitu pendidik akan lebih mudah dalam menyampaikan materi dan peserta pendidik juga dapat lebih mudah dalam memahami materi. Diskusi dan tanya jawab bisa dilakukan secara langsung seperti perkuliahan tatap muka di kelas (Yulianto, Cahyani, \& Silvianita, 2020). Pendidik dan peserta pendidik hadir pada kelas virtual sesuai dengan jadwal tatap muka offline.

Sayangnya pendekatan e-learning menggunakan tipe komunikasi synchronous ini bukan tanpa masalah. Keluhan yang muncul dari peserta didik diantaranya terkait tingginya konsumsi data aplikasi-aplikasi sejenis zoom meeting dan google meet. Selain itu apabila jaringan internet tidak stabil maka akan menggangu proses belajar, karena tampilan video dan suara menjadi terputusputus sehingga peserta didik tidak bisa memahami apa yang disampaikan oleh pendidik.

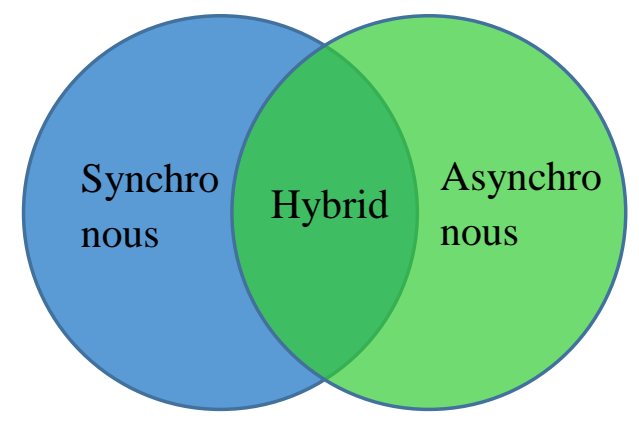

\section{Gambar 4. Kombinasi Tipe Komunikasi dalam E-learning}

Berdasarkan analisis tersebut maka agar pembelajaran daring lebih efektif maka e-learning atau PJJ daring sebaiknya mengkombinasikan dua pendekatan komunikasi yang ada yaitu komunikasi synchronous dan asynchronous yang biasa disebut dengan istilah hybrid.
Tahapan pembelajaran dalam elearning menggunakan komunikasi hybrid dapat dijelaskan sebagai berikut:

1) Tahapan pra pembelajaran

a) Pendidik membuat grup WA dan mengundang seluruh peserta didik ke grup WA

b) Pendidik menyiapkan rencana pembelajaran dalam satu semester

c) Pendidik mengunggah materi (bahan bacaan atau powerpoint) ke Google Classroom

d) Pendidik membuat rekaman video materi pembelajaran yang diunggah ke youtube

e) Pendidik menyiapkan latihan soal menggunakan aplikasi Quizziz atau Google Form

2) Tahapan pelaksanaan pembelajaran

a) Pendidik menyampaikan prosedur pembelajaran melalui grup WA (Asynchronous)

b) Pendidik mengarahkan peserta didik untuk mengunduh dan mempelajari materi yang ada di google form atau youtube (Asynchronous)

c) Pendidik dan peserta didik melakukan komunikasi synchronous dalam bentuk pertemuan virtual melalui grup WA (live chat) sesuai dengan jadwal kegiatan tatap muka, dengan kegiatan antara lain:

- Pendidik mendeskripsikan materi pembelajaran menggunakan pesan teks atau pesan suara

- Diskusi interaktif materi pembelajaran melalui pesan teks

- Pendidik membagikan tautan presensi google form yang harus diisi peserta didik selama proses pembelajaran berlangsung

- Diakhir pertemuan, pendidik membagikan link latihan soal menggunakan quizziz atau fitur kuis pada google classroom

d) Dalam satu semester melakukan tatap muka virtual sebanyak 3-4 kali menggunakan Zoom Meeting, 
Google Meet atau Microsoft Team. Kegiatan pembelajaran yang dilakukan menggunakan live chat WA (Synchronous)

e) Peserta didik mengerjakan latihan soal pada quizziz atau google classroom

f) Peserta didik mempelajari materi untuk pertemuan berikutnya

\section{PENUTUP}

\section{Simpulan Dan Saran}

Tipe komunikasi dalam metode PJJ daring dapat dibedakan menjadi 2 yaitu tipe komunikasi synchronous dan tipe komunikasi asynchronous. Tipe komunikasi synchronous terjadi ketika proses pembelajaran antara pendidik dan peserta didik dilakukan pada saat yang sama. Sedangkan komunikasi asynchronous terjadi ketika pendidik dan peserta didik tidak bertemu pada ruang virtual secara bersamaan. Pemilihan tipe komunikasi tersebut dipengaruhi oleh media komunikasi yng digunakan oleh pendidik dan peserta didik.

Berdasarkan hasil penelitian yang dilakukan, menunjukkan bahwa proses pembelajaran yang berlangsung saat ini, sebagian besar mengkombinasikan kedua tipe komunikasi synchronous dan asynchronous. Kombinasi tipe komunikasi ini sering disebut sebagai komunikasi hybrid. Karena komunikasi ini diterapkan pada PJJ daring, maka dapat juga diistilahkan PJJ daring hybrid.

Dalam memilih media komunikasi yang dimanfaatkan untuk PJJ daring (elearning), pendidik mempertimbangkan beberapa faktor, antara lain: (1) konsumsi kuota data, (2) kemudahan penggunaan (user friendly), dan (3) kondisi infrastruktur jaringan, serta (4) kesesuaian dengan aktivitas pembelajaran.

Dari sekian banyak aplikasi atau media komunikasi yang ada dipasaran, pendidik dan peserta didik memiliki preferensi yang tinggi terhadap beberapa aplikasi, yaitu: Whatsapp, Zoom Meeting, Google meet, Microsoft team, Google Clasroom, Google form, Quizziz.

\section{DAFTAR PUSTAKA}

Aji, R. H. S. (2020). Dampak Covid-19 pada Pendidikan di Indonesia: Sekolah, Keterampilan, dan Proses Pembelajaran. Salam: Jurnal Sosial Dan Budaya SyarI., 7(5), 395-402.

Almah, U., Thohari, M. I., \& Lismanda, Y. F. (2020). Pemanfaatan teknologi pembelajaran pendidikan agama islam di tengah masa pandemi covid-19 berbasis social distancing di smkn 5 Malang. Vicratina: Jurnal Pendidikan Islam., 5(10), 134-142.

Arifa, F. N. (2020). Tantangan Pelaksanaan Kebijakan Belajar Dari Rumah Dalam Masa Darurat Covid-19. Info Singkat;Kajian Singkat Terhadap Isu Aktual Dan Strategis, XII(7/I), 6. Retrieved from http://berkas.dpr.go.id/puslit/files/info_ singkat/Info Singkat-XII-7-I-P3DIApril-2020-1953.pdf

Asmuni, A. (2020). Problematika Pembelajaran Daring di Masa Pandemi Covid-19 dan Solusi Pemecahannya. Jurnal Paedagogy, 7(4).

Astini, N. K. S. (2020). Tantangan Dan Peluang Pemanfaatan Teknologi Informasi Dalam Pembelajaran Online Masa Covid-19. Cetta: Jurnal Ilmu Pendidikan, 3(2), 241-255.

Ayuni, D., Marini, T., Fauziddin, M., \& Pahrul, Y. (2020). Kesiapan Guru TK Menghadapi Pembelajaran Daring Masa Pandemi Covid-19. Jurnal Obsesi: Jurnal Pendidikan Anak Usia DiniPendidikan Anak Usia Dini, 5(1), 414-421. 
CNNI. (2020). Kemendikbud buat skenario belajar di rumah sampai akhir. CNNN Indonesia. Retrieved from https://www.cnnindonesia.com/nasional /20200424114337-20-

496861/kemendikbud-buat-skenariobelajar-di-rumah-sampai-akhir-2020

Daheri, M., Juliana, Deriwanto, \& Amda, A. D. (2020). Efektifitas WhatsApp sebagai Media Belajar Daring. Jurnal Basicedu, $3(2)$, 524-532. https://doi.org/10.31004/basicedu.v4i4. 445

Darmawan, E. (2018). IMPLEMENTASI MODEL PEMBELAJARAN ASYNCHRONOUS DALAM PERANCANGAN APLIKASI SIMULASI PANDUAN PECINTA ALAM BERBASIS ANDROID. Cloud Information, 3(2).

Dewi, W. A. F. (2020). Dampak Covid-19 terhadap implementasi pembelajaran daring di Sekolah Dasar. Edukatif: Jurnal Ilmu Pendidikan, 2(1), 55-61.

Fahmi, M. H., \& Cipta, B. S. I. (2020). Pengembangan Blended Learning Berbasis Moodle (Studi Kasus Di Universitas Islam Raden Rahmat Malang). Jurnal Teknologi Terapan: GTech, 2(1), 106-113. https://doi.org/10.33379/gtech.v2i1.328

Isbaniah, F. (2020). Pedoman Pencegahan dan Pengendalian Corona Virus Disease (Covid-19). Retrieved from https://repository.ugm.ac.id/276196/1/P edoman Pencegahan dan Pengendalian Coronavirus Disease \%28COVID19\%29 - Kemenkes.pdf

Kementerian Pendidikan Dan Kebudayaan. (2020). Pedoman Penyelenggaraan Belajar Dari Rumah Dalam Masa Darurat Penyebaran Corona Virus Disease (Covid-19). Surat Edaran Nomor 15 Tahun 2O2O, pp. 1-20.
Kemp, S. (2020). DIGITAL 2020: 3.8 BILLION PEOPLE USE SOCIAL MEDIA. Hootsuite. Retrieved from https://wearesocial.com/blog/2020/01/d igital-2020-3-8-billion-people-usesocial-media

Kompas. (2020). Wabah Corona , ini Tanggapan Kemendikbud tentang Meliburkan Sekolah.

Maizan, S. H., Bashori, K., \& Hayati, E. N. (2020). ANALYTICAL THEORY: GEGAR BUDAYA (CULTURE SHOCK). Psycho Idea, 18(2), 147-154.

Napitupulu, R. M. (2020). Dampak pandemi Covid-19 terhadap kepuasan pembelajaran jarak jauh. Jurnal Inovasi Teknologi Pendidikan, 7(1), 23-33., 7(1), 23.

Prodjo, W. A. (2020). Mendikbud Nadiem Makarim: 429 Kota/Kabupen di Indonesia Dilarang Membuka Sekolah. Kompas.Com. Retrieved from https://www.kompas.com/edu/read/202 0/06/15/180224171/mendikbudnadiem-makarim-429-kota-kabupen-diindonesia-dilarang-membuka

Rigianti, H. A. (2020). Kendala Pembelajaran Daring Guru Sekolah Dasar di Banjarnegara. Elementary School: Jurnal Pendidikan Dan Pembelajaran $\mathrm{Ke}-\mathrm{SD}-\mathrm{An}, \mathrm{7}(2)$.

Satrianingrum, A. P., \& Prasetyo, I. (2020). Persepsi Guru Dampak Pandemi Covid19 terhadap Pelaksanaan Pembelajaran Daring di PAUD. Jurnal Obsesi: Jurnal Pendidikan Anak Usia Dini, 5(1), 633640.

Setiyaningsih, L. A., \& Jatmikowati, S. H. (2019). Media Baru Dalam Komodifikasi Waktu Luang Ibu Rumah Tangga. ETTISAL: Journal of Communication, 4(1), 25. https://doi.org/10.21111/ettisal.v4i1.30 


\section{JURNAL NOMOSLECA}

Volume 6 Nomor 2, Oktober 2020

69

Suranto, B. (2019). Virtual Classroom: Strategi Pembelajaran Berbasis Synchronous E-Learning. Seminar Nasional Aplikasi Teknologi Informasi (SNATI).

Taradisa, Nidia., Jarmita, Nida., E. (2020). Kendala Yang Dihadapi Guru Mengajar Daring Pada Masa Pandemi COvid 19 MIN 5 Banda Aceh. UIN Ar-Raniry Banda Aceh, 1(1), 23. https://doi.org/10.1017/CBO978110741 5324.004

Tempo. (2020). Daerah-Daerah Meliburkan Sekolah Untuk Antisipasi Corona. Tempo. Retrieved from https://nasional.tempo.co/read/1319734 /daerah-daerah-yang-meliburkansekolah-untuk-antisipasicorona/full\&view $=$ ok

Yulianto, E., Cahyani, P. D., \& Silvianita, S.
(2020). Perbandingan Kehadiran Sosial dalam Pembelajaran Daring Menggunakan Whatsapp groupdan Webinar Zoom Berdasarkan Sudut Pandang Pembelajar Pada Masa Pandemic COVID-19. JARTIKA Jurnal Riset Teknologi Dan Inovasi Pendidikan, 3(2), 331-341. https://doi.org/10.36765/jartika.v3i2.27 7

Yunus, N. R., \& Rezki, A. (2020). Kebijakan Pemberlakuan Lockdown Sebagai Antisipasi Penyebaran Corona Virus Covid-19. SALAM; Jurnal Sosial \& Budaya Syar-I, 7(3), 227-238. https://doi.org/10.15408/sjsbs.v7i3.150 83

Zahrotunnimah, Z. (2020). Langkah Taktis Pemerintah Daerah Dalam Pencegahan Penyebaran Virus Corona Covid-19 di Indonesia. SALAM: Jurnal Sosial Dan Budaya Syar-I, 7(3), 247-260. 